\title{
CETICISMO E CRENÇA RELIGIOSA NO TRATADO DA NATUREZA HUMANA*
}

\author{
Livia Guimarães** \\ liviamguimaraes@gmail.com
}

A Richard Popkin, devemos uma poderosa visão unificadora do ceticismo consequente ao debate religioso do início da modernidade. Na História do Ceticismo, Popkin interpreta a controvérsia que se segue à reforma protestante segundo o modelo da crítica pirrônica antiga aos critérios de certeza dogmáticos. ${ }^{1}$ Em sua interpretação, assim como a dos antigos, a busca dos modernos acaba no abandono da esperança de jamais se encontrar ou satisfazer um critério. Este fracasso faz com que se substitua a razão por uma espécie de fideísmo, que consiste, aqui, no assentimento a crenças que, apesar de racionalmente injustificáveis, provam-se duradouras apesar da, e mesmo em oposição à razão. Em seguida, Popkin mostra que a crise pyrrhonienne acaba por extrapolar a esfera religiosa e por moldar a própria filosofia moderna, quando conhecimento degrada-se em crença e, em alguns casos, em "pura fé animal".

A coletânea The High Road to Pyrrhonism, ao avaliar o pensamento de Hume, complementa esta visão. Para Popkin, Hume emerge na cena do pensamento filosófico como "único cético vivo" ("only living skeptic") no século XVIII - "por um lado, um anacronismo e, por outro, o homem mais

* "Skepticism and Religious Belief in A Treatise of Human Nature", in J. R. Maia Neto, G. Paganini, J. C. Laursen (orgs.), Skepticism in the Modern Age: Building on the Work of Richard Popkin. Leiden: Brill, 2009, 345-364.

** Departamento de Filosofia/UFMG, CNPq. Artigo recebido em 28/11/2011 e aprovado em 29/11/2011.

1 Popkin, Richard H., The History of Scepticism from Erasmus to Spinoza. Berkeley and Los Angeles: University of California Press, 1979. Na tradução de Danilo Marcondes de Souza Filho, História do Ceticismo de Erasmo a Spinoza. Rio de Janeiro: Francisco Alves, 2000. 
consciente da nova condição trazida pelo Iluminismo - onde nenhuma fé, que possa servir de guia aos seres humanos, sobrevive". 2

O Hume de Popkin representa a insolúvel tensão entre o ceticismo de Bayle e o otimismo dos moralistas escoceses, entre construção empírica e científica e desconstrução pirrônica. Apesar do esforço no sentido de se tornar o "Newton da moral", Hume destrói, com seu ceticismo, tudo o que antes havia edificado. Profundamente atormentado, "já "iluminado em excesso" para encontrar repouso ou paz em qualquer tradição religiosa", ele

pode apenas se maravilhar diante do fato de a Natureza vir sempre em nosso socorro, ao irracionalmente dar sustentação à nossa fraca razão e tornar psicologicamente impossível levarmos a dúvida a sério, deixando, assim, o ser humano capaz de praticar ciência empírica, nos intervalos em que sua mente não volta a ser tomada pela dúvida. ("Randall and British Empiricism", HR 52)

\section{Um "verdadeiro pirronista", ele}

É tambos dogmático e cético. Por ser inteiramente produto da natureza, ele merge sua filosofia e sua personalidade esquizofrênica ... a imagem dos dois, o dogmático e o cético, é uma imagem do pirronista perfeito em seus dois estados, sua personalidade dividida. . ("Hume's Pyrrhonism and Critique of Pyrrhonism", HR 130-132)

\section{A metáfora retorna na descrição de Popkin do Tratado:}

O resultado esquizofrênico de um psicologismo otimista, que viria explicar todos os projetos intelectuais humanos, e um ceticismo desesperado quanto à possibilidade de se explicar coisa alguma, acabou no total desespero do autor na conclusão do livro 1. Ele poderia apenas alternar entre ser um cientista social newtoniano positivo e um completo cético, tudo sabotando, inclusive suas próprias conquistas científicas. ("Skepticism and Anti-Skepticism in the Latter Part of the Eighteenth Century", HR 56)

2 No original: "on the one hand an anachronism, and on the other, the man who was most aware of the new predicament created by the Enlightenment - that there was no faith left to guide men." Cf. Popkin, Richard H., The High Road to Pyrrhonism. San Diego: Austin Hill Press, 1980, 58. Em referências futuras: "HR". A descrição de Hume como 'o único cético vivo' data do artigo de 1976, "Skepticism and Anti-Skepticism in the Latter Part of the Eighteenth Century". Posteriormente, Popkin abandonou esta posição. Cf. o volume que editou com Giorgio Tonelli e Ezequiel de Olaso: Scepticism in the Enlightenment. Dordrecht: Kluwer, 1997. Em referências futuras: "SE".

3 No original: "could only marvel at the fact that Nature always saved the day by irrationally sustaining our feeble reason, and making it psychologically impossible to take the doubt seriously, thereby leaving man able to do empirical science now and then until his mind once again becomes overheated with doubts."

4 No original: "is both a dogmatist and a skeptic. In being entirely the product of nature he welds his schizophrenic personality and philosophy together ...the picture of the two, the dogmatist and skeptic, is a picture of the perfect Pyrrhonist in his two moods, his split personality."

5 No original: "The schizophrenic result of an optimistic psychologism that would explain all of man's intellectual endeavors and a desperate skepticism about whether anything could be explained, ended in the utter dismay of the author in the conclusion of the first book. He could only alternate between being 


\section{E também na afirmação de que}

A crise cética nunca se resolve, sendo apenas temporariamente subjugada pela natureza. Estamos condenados a uma existência esquizofrênica, alternando entre a descoberta de que não podemos encontrar verdade e certeza em lugar nenhum, e viver dogmaticamente como se as tivéssemos encontrado. ${ }^{6}$ ("Scepticism in the Enlightenment", SE 7)

Expressões tais como "uma figura desesperada", "condenada", "dividida", "angustiada", abundam no texto. ${ }^{7} \mathrm{O}$ modelo de Popkin alterna dúvida e certeza, construção e desconstrução, dogmatismo e ceticismo, e assim traça uma padrão geral na filosofia de Hume.

Neste ensaio, pretendo examinar a explicação naturalista das crenças religiosas no Tratado da natureza humana. Em mais de um sentido, minha abordagem é guiada pela de Popkin: ela situa a fé ou religião no interior de um arcabouço epistêmico mais amplo, e discerne estados intermediários entre crença e descrença. Mais especulativamente, mas ainda inspirada pela interpretação do ceticismo de Hume segundo Popkin, o ensaio também aponta a tensão (expressa de maneira acabada somente no trabalho posterior ao Tratado) resultante do contraste entre a fraqueza das bases da religião e a força de sua influência. $\mathrm{Na}$ visão de Popkin, oscilação, instabilidade, e consequente perplexidade, são características da mente do próprio Hume. Parece-me que, de modo curioso, estas são características arraigadas da experiência e crença religiosa humana, às quais se deve boa parte das dificuldades de nossas vidas, na visão de Hume.

\section{O contexto moderno: religião na natureza}

Na filosofia dos séculos XVII e XVIIII, análises da religião frequentemente culminam na redução da crença a causas naturais. Em alguns casos, principia-

a positive Newtonian social scientist and a complete skeptic, undermining everything, including his own scientific achievements."

6 No original: "the sceptical crisis is never resolved, only temporarily abated by nature. We are condemned to a schizophrenic existence, alternating between realizing that we cannot find truth or certainty anywhere, and living dogmatically as if we had."

7 O texto diz: "Like him, we were doomed to be haunted by an unconquerable skepticism once we asked, in a post-Enlightenment world, What do we know? How do we know it? Why do we know it?" (HR 53). "When Hume came to sum up his achievement, he seemed to recognize the hopelessness of modern man, shorn of Divine Guidance and help, to find any answers to what he was, what his world was, or why it was" (HR 56-7). "We are torn between an inescapable and irrefutable skepticism and a natural, forced dogmatism" (HR 57). "Lastly, Hume, on my reading, is a really giant intellectual figure, not for his analytical philosophical brilliance or originality, since I have strong doubts as to whether he ever really possessed those qualities, but rather as a forlorn figure facing up to a world of complete Baylean skepticism, in which all anchors were gone, religious or scientific" (HR 52). 
se inferindo a religião a partir da ordem natural, apenas para, no fim, chegarse a modelos mecânicos e ateístas desta ordem. ${ }^{8}$ Em outros, procede-se a uma inferência causal a partir da natureza humana, abandonando-se a influência de um agente sobrenatural em favor das paixões, humores corpóreos, cálculo político, e intercurso social. Enquanto alguns descrevem uma tendência à religião na natureza humana, outros diagnosticam uma patologia da crença religiosa. ${ }^{9}$

Embora os autores coincidam na busca de uma explicação natural, a forma e extensão desta explicação varia imensamente, bem como varia a avaliação do papel da religião. As críticas iniciais têm por único alvo a falsa religião, ou superstição, e estabelecem linhas divisórias entre cristãos e não-cristãos. "Superstição" primeiro designa pagãos. Com o passar do tempo, vem designar seitas cristãs não ortodoxas, a própria cristandade e, em última instância, crença no sobrenatural, qualquer que seja ela.

Onde subsiste a distinção entre religião verdadeira e falsa, a superstição, obviamente, inclina-se para o lado do erro, denotando tanto crentes crédulos, quanto crenças infundadas. Mas, mais audaciosamente, por vezes, a distinção se faz entre crenças válidas e todas as crenças de natureza religiosa, ou todas as crenças que ultrapassam o conhecimento e evidência. Credulidade é a falta epistêmica mais comumente criticada. Junto a uma perspectiva cognitiva que se volta para o entendimento e acentua o conceito de ignorância, há também uma perspectiva moral que se volta para as paixões, tende a acentuar o medo, e vê na superstição um sinal de ansiedade e terror.

Em sua expressão moral, a naturalização segue-se à explicação de fenômenos religiosos pelas paixões ou por interesses políticos, às vezes denunciando a manipulação eclesiástica, sustentada por ignorância crédula, outras vezes diagnosticando mentes desordenadas e enfermas. Muitos associam a psicologia das paixões à fisiologia dos humores ou espíritos animais e atribuem o surgimento da superstição a seu desequilíbrio. É assim que a superstição emerge como uma doença - produto de uma imaginação excessivamente ativa (e.g. Spinoza), ou de paixões melancólicas (e.g. Trenchard). Muitos situam sua causa em um defeito da razão e em artifícios

8 É este o caso, por exemplo, do deísmo francês representado em D'Holbach's Sistema da natureza.

9 De fato, um passo importante na naturalização da religião na modernidade consiste em se considerar a superstição não uma obra de demônios, mas sintoma de uma enfermidade. O problema acerca da existência de bruxas exibe um curioso desenvolvimento paralelo. A visão que culmina em Hutcheson diagnostica, nas bruxas, sofredoras de delírio melancólico. Os oponentes desta visão, como Glanvill e outros, não apenas defendem o caráter sobrenatural da bruxaria, mas também advertem que negá-lo pode, eventualmente, levar à negação de todo o reino sobrenatural e da existência mesma de Deus. 
políticos (e.g. Hobbes, Mandeville). No fim, quase nenhum espaço resta para a religião verdadeira, ou religião sem superstição. Bayle, talvez mais do que qualquer outro autor, facilita este progresso, ao estabelecer uma linha contínua entre idolatria pagã e idolatria cristã.

Para Hume, seu herdeiro legítimo, a classe dos supersticiosos e a classe de todos os crentes no sobrenatural, ou "religionistas" (religionists), são coextensivas. ${ }^{10}$ Em uma palavra, são supersticiosos os que possuem crenças contrárias à experiência comum. Mas, para Hume, a superstição pode surgir em qualquer época e lugar e somos, todos nós, propensos a ela. Hume não a limita aos cultos pagãos antigos, ou a determinadas formas do culto cristão; e não a confina a povos remotos no espaço e tempo. Seguindo Bayle, não prevê sua derrocada ao fim do progresso ilustrado. Pessimista, considera-a sempre presente no espaço das possibilidades. Em sua análise, ela é, de uma estranha maneira, "natural".

Hume responde às várias preocupações de seus antecessores com uma análise sociológica, política e psicológica das paixões religiosas. Ele atenta à aparição da religião como vício e como doença e, assim como os deístas, denuncia o zelo e fanatismo religioso. Mas, diferentemente deles, não se deixa tocar pela "mística" da religião natural. Além disso, seu argumento não atribui grande papel à fisiologia, optando por um estudo independente e restrito ao funcionamento da mente - e também isso o distingue de outros autores. Por fim, com frequência, ele desconsidera os argumentos teológicos. Em seu tempo, para alguns (entre os quais, sem dúvida, inclui-se Hume), os teólogos já não eram interlocutores privilegiados e, nem sequer, oponentes privilegiados - suas doutrinas tendo se convertido em objetos dos curiosos.

\section{O Tratado da natureza humana: uma análise naturalista da religião}

Como exatamente crenças religiosas aparecem à luz do programa naturalizante de Hume? Segundo importantes interpretações de seu pensamento, é preciso que se aborde a religião para que se dê lugar à ciência do homem. Nestas interpretações, a crítica da religião é mais que um item na

10 Utilizo o termo 'superstição' em sentido bastante amplo. Em alguns de seus usos, a superstição contrasta com o fanatismo e entusiasmo. Em outros, tem maior abrangência, incluindo o fanatismo como subgrupo. Um exemplo, seria a "História natural da religião" onde, creio, superstição representa todas as religiões vulgares. Do mesmo modo, em alguns usos, superstição significa a religião resultante de causas naturais, em oposição a religião justificada racionalmente. Deixando de lado a questão de uma religião da razão (abordada por Hume nos Diálogos sobre a religião natural) vou me concentrar, neste ensaio, em sua aparência como uma crença "natural", no Tratado. 
extensa lista de objetos sob investigação. Ela emerge, antes, como condição necessária da filosofia de Hume - a ciência da natureza humana, teoria dos sentimentos morais, empirismo e, obviamente, o ceticismo, apoiando-se na rejeição de premissas religiosas e teológicas. ${ }^{11}$

Em Hume, naturalização certamente significa a metodologia empírica, inspirada por Bacon e Newton. Mas significa também liberdade filosófica frente a princípios teológicos. ${ }^{12}$ Um outro sentido marcante de seu naturalismo está em ele destituir proposições religiosas do tratamento diferenciado, antes garantido por tradicionais privilégios epistêmicos. Assim, em um sentido geral, naturalismo no Tratado pode se entender como recusa de pressupostos religiosos na metafísica. Mais especificamente, entende-se como explicação das crenças religiosas sem apelo ou recurso a princípios sobrenaturais. ${ }^{13} \mathrm{~A}$ seguir, procurarei enfocar o segundo destes desafios, ou seja, determinar os

11 Paul Russell, um defensor eminente desta visão, elabora-a em uma série de artigos que culmina em seu livro de 1995, Freedom and Moral Sentiment. Oxford: Oxford University Press.

12 A simples falta de apelos a princípios divinos ou teológicos já deveria indicar que o livro sustenta-se sobre o discrédito de concepções religiosas (mesmo que implicitamente), ou, ao menos, em quieta indiferença em relação a eles. Os contemporâneos de Hume tomaram isso como um revelador indício de infidelidade. Provavelmente, assim se explica porque, apesar de evitar a crítica aberta à prática e crença cristã, o Tratado, entretanto, deu origem à fama de Hume como sendo um cético infiel. Como sabemos, deveu-se ao Tratado o fracasso de Hume na obtenção de postos universitários em Edimburgo (1745) e Glasgow (1752). Na campanha para que a Assembleia Geral da Igreja escocesa o censurasse, os adversários denunciaram as consequências nocivas à religião de suas teorias, por exemplo, apontando que a negação da necessidade causal afeta o argumento cosmológico para a existência de Deus. As mesmas acusações reaparecem no imensamente bem-sucedido livro de Beattie Enquiry on the Nature and immutability of Truth. Beattie infere irreligião da filosofia de Hume e, da irreligião, ele infere imoralidade. Sua lista das numerosas teses anti-cristãs do Tratado inclui:

"That it is unreasonable to believe GOD to be infinitely wise and good, while there is any evil or disorder in the universe.

That we have no good reason to think the universe proceeds from a cause.

That as the existence of the external world is questionable, we are at a loss to find arguments by which we may prove the existence of the Supreme Being, or any of his attributes.

That when we speak of Power, as an attribute of any being, GOD himself not excepted, we use words without meaning.

That we can form no idea of power, nor of any being endued with power, much less of one endued with infinite power, and that we can never have reason to believe, that any object, or quality of any object exists, of which we can form an idea." Cf. o resumo dos argumentos de Beattie por George Horne em James Fieser, Early Responses to Hume's Life and Reputation, 2 vols. Bristol: Thoemmes Press, 2003, vol.1, 396-7.

13 No envolvimento direto do Tratado com a religião, muito da (mas não toda a) crítica posterior de Hume já se coloca. O Tratado adota uma perspectiva psicológica, que aponta causas naturais da religião, apesar de omitir suas causas sociais e políticas. Evidentemente, a omissão de "Dos milagres" constituise em uma perda para a sociologia do conhecimento. Também falta ao Tratado a análise da natural fraqueza e susceptibilidade humana à manipulação clerical, muito enfatizada por vários predecessores. Diferentemente daqueles que atribuem a origem da crença religiosa à manipulação do clero, Hume interpreta esta como sendo uma causa secundária, tanto porque ela se aplica a disposições passionais pré-existentes, quanto porque, para ele, as primeiras manifestações religiosas não são efeitos da interferência de sacerdotes nos assuntos humanos. Contudo, é certo que sacerdotes desempenham um papel importante no enredo das interações psicológicas e sociais. Hume nos remete às práticas da "igreja de Roma" como evidência do modo pelo qual eles instigam ou aplacam medos e, assim, adquirem imenso poder sobre os crentes. 
meios pelos quais a ciência da natureza humana explica a origem, ao mesmo tempo em que avalia o estatuto epistêmico destas crenças. O Tratado busca a origem da religião nos princípios da mente, ora em estados mentais ordinários, ora em estados enfermos. Ao fazê-lo, mostra como a associação de ideias e impressões sustenta e como ela solapa a religião, e mostra que os princípios de associação sustentadores são os mesmos que os subversivos.

É preciso enfatizar que, além de depender da teoria da crença, a análise da religião contribui para esta teoria. Na ciência da mente, a religião compartilha um padrão comum a outros tipos de crença e, através de seu estudo, Hume alcança maior compreensão do sentimento que se constitui em crença. Além disso, ele discerne uma categoria intermediária entre crença e descrença, que complementa sua teoria, pela introdução de um estado cognitivo distinto tanto do sentimento de determinação na probabilidade causal, quanto da inexistência desta determinação nas fantasias poéticas. Segundo Hume, por lhe faltarem bases causais estáveis e firmes, a crença religiosa acaba por ser sentida como quase descrença. É rara a consciência, nos crentes, do caráter peculiar desta maneira de sentir. Mas a maneira de sentir é, ela própria, comum e, nem mesmo quem se professa profundamente religioso, está isento dela.

Hume reconhece na religião um tema complexo. Ele se recusa a reduzila a mera hipocrisia - mesmo um hipócrita adquire um pouco das crenças fingidas - e considera a natureza humana, sob certas circunstâncias, propensa à superstição religiosa. Indolência natural promove a superstição, pois nos poupa o trabalho de investigar causas. A credulidade a promove ao nos dispor a acreditar no que nos é dito, somente porque nos foi dito. Hume observa, somos propensos antes a crer que a descrer nas asserções dos outros.

O caráter natural da religião, além de explicá-la, fornece um critério para se avaliar fenômenos religiosos diversos. Hume nota que, quanto mais conformes à natureza, maior será nossa inclinação a tolerá-los - este é, para ele, o caso do paganismo antigo. Os fenômenos que implicam violência contra nossa natureza tenderão a ser reprováveis ou, ao menos, suspeitos. Por exemplo, dada a inconstância e variabilidade da natureza humana, demonstrações exageradas de fé inabalável são claros indícios de hipocrisia.

Mas o caráter natural da religião jamais a justifica. Hume atribui naturalidade à religião, dada a sua origem sem, contudo, por isso, concederlhe legitimidade epistêmica ou moral. ${ }^{14}$ Tradicionalmente, para justificá-

14 No entanto, como a religião tem origem nas paixões, principalmente no medo (segundo a "História natural"), ela pode resistir à crítica racional e persistir tendo pouca razão, nenhuma razão, e mesmo apesar da razão - é o que geralmente ocorre. Com a ajuda de passagens como a do "exquisite 
la, apela-se à revelação, à razão, ou a ambas. É óbvio que, na perspectiva de Hume, não se pode estabelecer sua origem sobrenatural. Obtém-se igual resultado quando ele se volta para a "luz natural" da razão. ${ }^{15}$ Para Hume, religião permanece sempre um produto, por vezes, incorrigível, das paixões agravadas por ignorância.

Portanto, fiel a uma análise psicológica estrita, a ciência do homem do Tratado aborda, na religião, um fenômeno natural, não no sentido de crença necessária, universal e, menos ainda, verdadeira. Diríamos, então, que ela assume a aparência de uma enfermidade? Não exatamente. Por 'religião', Hume significa 'superstição'. Na "História natural”, ele, de fato, a define como "sonhos vãos de mentes doentias". Mas esta frase talvez seja mais feliz em seu efeito retórico que em sua acuidade. Embora haja uma faceta antirreligiosa militante em vários de seus escritos, no Tratado, todavia, Hume elege um outro tom, descritivo e teórico. É o que examinaremos a seguir.

\section{Crença no Tratado}

A abordagem de Hume no Tratado centra-se na mente, ou seja, mecanismos naturais de pensamento, tanto no entendimento, quanto nas paixões, dão conta dos processos mentais que resultam na crença religiosa e nela se observam. A questão do livro é, então: como esta crença emerge como efeito dos princípios da natureza humana?

Em suas palavras, a superstição "abre um "mundo" só seu, e nos apresenta cenas, seres e objetos totalmente novos". Este "mundo" situa-se no interior do "universo" da imaginação. A fim de explicá-lo, é necessário que se explique, antes, esta faculdade. ${ }^{16}$ Em sentido amplo, a imaginação

argument" de Cleanthes nos Diálogos, esta característica leva alguns intérpretes a defender que, para Hume, religião é uma "crença natural" no mesmo sentido em que é natural a crença na causalidade, i.e. espontânea, universal e necessária. Uma intrigante linha de interpretação, assumida por Hamann (e observada por Popkin) no século XVIII, mantém que, ao reduzir o conhecimento à crença, Hume també reduz toda crença a fé, equiparando o pensamento causal ao religioso ("Skepticism and AntiSkepticism in the Latter Part of the Eighteenth Century" HR 74-5).

15 Uma versão diria que a crença religiosa evolui de sua origem inferior nas paixões para uma origem superior na contemplação racional da ordem natural. O trabalho combinado da "História natural da religião" e dos Diálogos sobre a religião natural refuta esta versão. Para uma interessante discussão recente deste problema cf. Kail, Peter, “Understanding Hume's Natural History of Religion”, Philosophical Quarterly 87 (227), 2007: 190-211.

16 Ao discutir "existência", Hume diz: "Ora, como nada jamais está presente à mente além das percepções, e como todas as ideias são derivadas de algo anteriormente presente à mente, segue-se que nos é impossível sequer conceber ou formar uma ideia de alguma coisa especificamente diferente de ideias e impressões. Dirijamos nossa atenção para fora de nós mesmos tanto quanto possível; lancemos nossa imaginação até os céus, ou até os limites extemos do universo. Na realidade, jamais avançamos um passo sequer além de nós mesmos, nem somos capazes de conceber um tipo de existência diferente 
é a faculdade de associar ideias e impressões. Percepções na mente não se encontram inteiramente soltas e desconexas, nem se conectam por simples acaso. Há qualidades pelas quais uma impressão naturalmente introduz outra, e uniformidade em sua associação. Como sabemos, Hume descreve semelhança, contiguidade e causa e efeito - os princípios de associação - com uma "força gentil", apontada pela natureza. Mas estes princípios nem são infalíveis, nem são os únicos que atuam. É comum, por exemplo, acidente e educação tomarem o lugar da natureza na associação de ideias ( $\mathrm{T}$ 1.3.6.13).

Em sentido estrito, a imaginação difere da memória e da razão por sua inferior força e vividez. Em contraste com a memória, uma "percepção [na imaginação] é fraca e lânguida, e apenas com muita dificuldade pode ser conservada firme e uniforme pela mente durante um período considerável de tempo" (T 1.1.3.1). Em um contraste paralelo, a associação de ideias constituise em crença se resulta do princípio causal, ou se constitui em mera concepção, se "imaginada" ou "fantasiada".

Um ato da mente, a crença consiste na "concepção forte e firme de uma ideia, aproximando-se em grande medida de uma impressão imediata" (T 1.3.5 nota). Hume afirma que a diferença entre conceber e crer está na maneira de concepção. Em suas palavras: "a crença nada mais faz que variar a maneira pela qual concebemos qualquer objeto, ela pode apenas conceder a nossas ideias força e vividez adicional" (T 1.3.7.5). Estas são marcas características dos sentidos e da memória ( $\mathrm{T}$ 1.3.5.7).

Hume primeiro define crença como "uma ideia relacionada ou associada a uma impressão presente" ( $\mathrm{T}$ 1.3.6.15). Ele propõe uma definição mais exata ao caracterizá-la como "uma ideia vívida relacionada ou associada a uma impressão presente" ( $\mathrm{T}$ 1.3.7.5), e como uma "concepção mais vívida e intensa de uma ideia, procedente de sua relação a uma impressão presente" (T 1.3.8.11).

Curiosamente, muitos dos exemplos da formação ordinária de crenças no Tratado vêm da religião. Para exemplificar a superior influência de objetos sensíveis, Hume cita as cerimônias católicas e o fortalecimento da experiência religiosa através do uso de imagens e objetos sagrados. Para exemplificar o princípio de contiguidade, ele cita peregrinações muçulmanas e cristãs. Para a causação, ele aponta a adoração de relíquias.

das percepções que apareceram dentro desses estreitos limites. Tal é o universo da imaginação, e não possuímos nenhuma ideia senão as que ali se produzem", Hume, David, Tratado da natureza humana. Trad. Déborah Danowski, São Paulo: Unesp, 2000, 1.2.6.8. Em referências futuras: "T". 
O mecanismo que vivifica ideias pela transição de uma impressão presente naturalmente regula a operação das ideias sobre as paixões, provê bases seguras para assentimento e crença, e distingue verdade e falsidade. Não é qualquer vã concepção que move nosso pensamento. ${ }^{17} \mathrm{Mas}$, em alguns casos, impressões e ideias, ou sentimentos e pensamentos "chegam bem perto uns dos outros".

O passar do tempo faz com que uma ideia de memória vá se enfraquecendo gradativamente. Às vezes, embora as impressões originais já estejam "totalmente apagadas da memória, a convicção que elas algum dia produziram permanece forte" ( $\mathrm{T}$ 1.3.4.3). Outras vezes, a memória torna-se quase indistinguível de uma simples concepção imaginária. É ainda possível que "uma ideia da imaginação adquira uma tal força e vividez que ela se faz passar por uma ideia da memória e imita seus efeitos na crença e no juízo" ( $T$ 1.3.5.6). ${ }^{18}$

Sempre extrapolamos os limites da experiência ao aplicarmos regras gerais. Poemas e romances produzem imagens vívidas "onde a natureza se confunde por completo". O mesmo fazem os sonhos, febre, loucura, e até a contínua repetição de uma mentira. Embora o padrão ordinário ou comum usualmente prevaleça, e apenas raramente as ideias operem indistintamente, a ponto de apagar a linha divisória entre pensar e crer, a crença pode surgir como resultado de vários fatores outros que o sentido, a memória e a experiência passada. Para Hume, é o que ocorre na loucura (T 1.3.10.9). Este pode, talvez, ser também o caso da religião.

\section{Crença religiosa}

O Tratado levanta a seguinte questão: até onde a natureza promove a religião? E, simultânea: em que ponto a natureza a neutraliza? Religião é, de certo modo, natural à mente humana. De fato, como sabemos, mesmo quando fruto da insinceridade, ela logo vem a se tornar sincera. E, quando não surge naturalmente, ou seja, não espontaneamente, pode se fazer surgir por meios naturais.

17 Do contrário, "estaríamos sujeitos às maiores calamidades", e nossa mente "jamais gozaria de um momento sequer de paz e tranquilidade" ( $T$ 1.3.10.2).

18 Hume observa que, por um lado, "no sono, no delírio febril, na loucura, ou em qualquer emoção mais violenta da alma, nossas ideias podem se aproximar de nossas impressões. Por outro lado, acontece, às vezes, de nossas impressões serem tão apagadas e fracas que não somos capazes de as distinguir de nossas ideias" (T 1.1.1). 
Embora natural, ela não é um fenômeno ou ocorrência estável ou duradoura. Sua naturalidade, por seu turno, como já apontamos, resume-se a indolência, credulidade e ignorância naturais. Apontamos ainda que Hume, de certo modo, aceita (sem, contudo, aprovar) variedades religiosas mais afinadas à natureza humana. ${ }^{19}$ Mas, estas, ele aceita como algo difícil de se extirpar de nossa existência. ${ }^{20}$

No sentido estrito, a superstição religiosa designa os católicos. Apesar de "Da superstição e entusiasmo" vir a enfatizar a dominação eclesiástica, no Tratado, a superstição católica consiste no recurso a rituais e objetos sensíveis, que tomam o lugar e representam os princípios imateriais da fé cristã, ${ }^{21}$ e no culto a relíquias, tidas como efeitos dos santos. Como diz Hume:

Quando criticados, os devotos dessa estranha superstição costumam justificar toda aquela sua pantomina, alegando que seus movimentos, posturas e ações exteriores lhes são benéficos, por revitalizar sua devoção e estimular seu fervor, os quais, de outro modo, se dirigidos inteiramente para objetos distantes e imateriais, acabariam por se apagar. ( $\mathrm{T}$ 1.3.8.4)

Aqui, interessa a Hume antes a compreensão de um mecanismo, que a crítica a intenções ocultas do clero. Nos movimentos regulares da mente, a fundação da religião em princípios naturais pode ser refletida, ou não. O catolicismo apoiase na exploração deliberada e consciente dos três princípios de associação. A influência da semelhança e contiguidade é muito fraca e incerta quando operam isoladamente (T 1.3.9.6). Instáveis e não confiáveis, elas são, todavia, bastante ativas:

Comecemos pela contiguidade. Observou-se, tanto entre os maometanos como entre os cristãos, que os peregrinos que estiveram em MECA ou na TERRA SANTA tornam-se para sempre crentes mais fiéis e zelosos que aqueles que nunca tiveram tal oportunidade. Um homem cuja memória apresenta uma imagem viva do Mar Vermelho, do deserto, de Jerusalém e da Galiléia jamais pode duvidar dos acontecimentos miraculosos relatados por Moisés ou pelos Evangelistas. A ideia vívida dos lugares passa, por uma transição fácil, aos fatos que se supõem terem sido relacionados a eles por contiguidade, e, ao aumentar a vividez da concepção, aumenta também a crença. (T 1.3.9.9)

19 Como veremos abaixo, um exemplo, no Tratado, poderia residir nas formas mais fracas de religião. Um exemplo mais substantivo, como sabemos, seria a superstição pagã, vista da perspectiva de seus benefícios morais, como apresentadas na "História natural da religião".

20 Nesse meio tempo, ele está fortemente comprometido com o combate à superstição dogmática que tem consequências perniciosas à felicidade e agência humanas, como, por exemplo em "Do suicídio".

21 Ver também Hume, David, Investigações sobre o entendimento humano e sobre os princípios da moral. Trad. José Oscar de Almeida Marques, São Paulo: Unesp, 2003, seção 5, parte 2. Em referências futuras: "EHU e "EPM". 
O uso religioso da proximidade sensível como meio vivificador da crença deve-se ao princípio segundo o qual uma impressão presente comunica sua vividez a qualquer ideia associada. Sensíveis, as relíquias são efeitos vívidos que emanam dos santos ou homens pios e são, por conseguinte, vivificadores de sua ideia. Igualmente, imagens sacras ajudam a vivificar idéias abstratas, remotas, gerais e distantes da compreensão comum.

Interações sociais servem-se de artifícios similares. Hume nota no Tratado que "a entrega das chaves de um celeiro é entendida como a cessão do trigo nele contido; a entrega de uma pedra e de um punhado de terra representa a cessão de um domínio" (T 3.2.4.2). Ele nota: "Essa é uma espécie de prática supersticiosa do direito civil e do direito natural, semelhante às superstições encontradas na religião católica romana”. Pois

Assim com os católicos romanos tornam os mistérios inconcebíveis da religião cristã mais presentes à mente, representando-os por meio de uma vela, de um hábito ou de gesticulações que supostamente se assemelham a eles, assim também os juristas e moralistas, pela mesma razão, lançaram mão de invenções semelhantes, buscando dessa forma satisfazer a si mesmos no que diz respeito à transferência da propriedade por consentimento. ( $\mathrm{T} 3.2 .4 .2$ )

Dá-se, aqui, uma fácil transição de ideias. Mas um desdobramento problemático pode vir (e usualmente vem) a ocorrer no caso da religião. Participantes da cerimônia civil não se esquecem do estatuto simbólico da chave do celeiro. Em contraste, os religionistas confundem (ou são induzidos a confundir) a coisa representada e aquilo que a representa. Eles atribuem poder causal real a este último, perdendo de vista seu propósito convencional e papel original. Os princípios naturais não operam em suas mentes com a mesma regularidade que nas alheias.

Outra característica da mente religiosa, já observada, é a credulidade. Hume afirma que credulidade é um universal da natureza humana (T 1.3.9.12); de fato, é sua mais conspícua fraqueza. No Tratado, ele a explica como sendo um subproduto espúrio da semelhança experienciada entre fatos e testemunho. ${ }^{22}$ Tendemos comumente a crer em testemunhos porque há (e deveria haver) uma

22 Como ele diz: "Mas, embora a experiência seja o verdadeiro critério deste, bem como de todos os outros juízos, raramente nos guiamos inteiramente por ela. Possuímos uma notável propensão a crer em tudo que nos é relatado, mesmo no caso de aparições, encantamentos e prodígios, por mais contrário que seja à experiência e observação diárias. As palavras ou discursos dos outros têm uma estreita conexão com certas ideias existentes em suas mentes; e essas ideias também têm uma conexão com os fatos ou objetos que representam. Esta última conexão é em geral muito superestimada, e induz nosso assentimento além do que seria justificável pela experiência - o que só pode proceder da semelhança entre as ideias e os fatos. Outros efeitos indicam suas causas apenas de maneira oblíqua; mas o testemunho humano o faz diretamente, devendo ser considerado não só um efeito, mas igualmente uma imagem" (T 1.3.9.12). 
relação causal entre fatos, ideias, e palavras. Na superstição, porém, crença em palavras e ideias surge mesmo na ausência da relação apropriada aos fatos. Além disso, esta relação não é meramente desconhecida; é improvável que ela exista.

Hume afirma que uma pessoa "é crédula em relação a tudo que alimente sua paixão dominante" (T 1.3.10.4). Ele sugere que o resultado da investigação de causas depende das paixões dominantes, que podem levar à verdadeira filosofia, à falsa filosofia, ou à superstição. Assim, as paixões determinam a crença de diversos modos, e a superstição descobre-se uma questão de paixão, tanto quanto do entendimento. ${ }^{23}$ Sacerdotes, que tentam aterrorizar seus seguidores para fortalecer as crenças, aproveitam-se de nossa preferência por estímulo (qualquer que seja) e aversão a estagnação. Eles exploram o fato que:

Assim como a crença é um requisito quase indispensável para despertar nossas paixões, também as paixões são, por sua vez, muito favoráveis à crença. Por esse motivo, não apenas os fatos que proporcionam emoções agradáveis, mas com frequência também os que provocam dor, tornam-se mais facilmente objetos de fé e convicção. (T 1.3.10.4)

\section{Admiração e o maravilhoso têm efeito semelhante: ${ }^{24}$}

Observamos que charlatães e aventureiros, graças às suas pretensões grandiosas, ganham a fé das pessoas comuns com mais facilidade do que se se mantivessem dentro dos limites da moderação. O espanto inicial que naturalmente acompanha seus relatos fantásticos se espalha por toda a alma, e vivifica e anima a ideia a tal ponto que acaba por torná-la semelhante às inferências que extraímos da experiência. ( $\mathrm{T}$ 1.3.10.4)

O temperamento peculiar do religionista agrava a "falta de firmeza e a instabilidade naturais tanto de nossa imaginação, quanto de nossos sentidos" (T 1.2.4.7). A passagem do Tratado constata que temos dificuldade em

23 Apenas a curiosidade ou amor à verdade produz a filosofia verdadeira (que é cética, pois apenas o ceticismo não lisonjeia nenhuma paixão irregular), enquanto a religião e as filosofias falsas são produzidas por paixões irregulares. Em oposição ao cético, o estoico luta para se colocar aparte da humanidade comum, e é governado pelo orgulho.

24 Bem cedo no Tratado, quando Hume procura explicar as razões porque filósofos têm sido atraídos pela ideia da infinita divisibilidade do espaço e tempo, ele nota que uma ideia tão obscura os seduz, em parte, por excitar sentimentos de admiração. Ele diz: "Tudo o que tem um ar de paradoxo e é contrário às primeiras noções da humanidade, às noções mais despidas de preconceito, costuma ser fervorosamente esposado pelos filósofos, como se mostrasse a superioridade de sua ciência, capaz de descobertas tão distantes da concepção vulgar. De outro lado, toda vez que alguém nos apresenta uma opinião que nos causa surpresa e admiração, é tal a satisfação que ela proporciona à mente, que ela se entrega por completo a essas emoçõe agradáveis, jamais se deixando persuadir de que seu prazer carece de todo e qualquer fundamento" (T 1.2.1.1). 
conceber e adquirir ideias adequadas de objetos diminutos. Também objetos grandiosos, tais como a origem e economia dos mundos, estão fora do escopo de nossas capacidades pensantes e cognoscentes. Nosso sistema estável da realidade deriva, como dissemos, do sentido, memória e causalidade. Já o sistema do religionista deriva de princípios menores, paixões irregulares e associações inadequadas. E, quando a religião aspira a apreender o maior de todos os objetos, ela "abre as portas para um mundo exclusivamente seu".

\section{Descrença religiosa}

A mesma propensão que origina falsas ciências e filosofias, é origem das fantasias sobrenaturais - otherworldly fantasies. ${ }^{25} \mathrm{O}$ Tratado define a religião como um "sistema da fantasia [fancy]". A fantasia, ou imaginação em suas características menos estáveis, contribui para a formação de crenças verdadeiras. Na probabilidade de causas, por exemplo, a certeza advém de a fantasia reunir "todas as imagens concordantes" extraindo delas uma única ideia ou imagem, "com uma intensidade e vividez proporcional ao número de experiências de que é derivada e à sua superioridade em relação às experiências antagônicas" (T 1.3.12.22). Mas um "sistema da fantasia" é algo totalmente distinto. As ideias que o formam possuem um sentimento ou maneira de concepção bem particular. A comparação entre crença e poesia talvez ilumine esta diferença.

Hume diz que a poesia "pode coletar mais daquelas circunstâncias que formam uma imagem ou quadro completo", pode nos apresentar uma descrição mais minuciosa de seu objeto, e pode ter um efeito mais sensível na imaginação que os sentidos e experiência. Por tais meios, ela capta nossa atenção e - para usar uma frase tradicional - "agita" os espíritos. Embora disponha seus objetos em cores mais vívidas, os sentimentos de suas ideias são meros fantasmas do sentimento que ocorre na mente quando raciocinamos sobre probabilidade, por menor que ela seja. Em outras palavras, as paixões são as mesmas, mas os sentimentos, não. Veemência não é o mesmo que força, e:

Quando a vividez surge de uma conjunção habitual com uma impressão presente, mesmo que aparentemente a imaginação possa não ser tão afetada, há sempre algo

25 Obviamente, as airy sciences são falsas metafísicas: "Não há nada tão necessário, para um verdadeiro filósofo, como a moderação do desejo excessivo de procurar causas; ele deve sentir-se satisfeito ao fundamentar uma determinada doutrina em um número suficiente de experimentos, se perceber que um exame mais prolongado o levaria a especulações obscuras e incertas" ( $T$ 1.1.4.6). 
mais imperativo e real em suas ações que no calor da poesia e da eloquência. ( $T$ 1.3.10.10)

Na poesia, uma ideia pode adquirir maior vividez, sem, contudo, nos afetar do modo como a crença o faz, pois nossa crença não cresce a cada vez que cresce a força e vividez das ideias ( $\mathrm{T}$ 1.3.10.12). Em comparação ao mero conceber ou pensar, a crença "torna as realidades mais presentes a nós que as ficções e faz que tenham um peso maior no pensamento, bem como uma influência superior sobre as paixões e a imaginação" (T 1.3.7.7). Ela é

Algo sentido pela mente, que permite distinguir as ideias do juízo das ficções da imaginação. A crença dá a essas ideias mais força e influência; faz que pareçam mais importantes, fixa-as na mente; e as torna os princípios reguladores de todas as nossas ações. (T 1.3.7.7)

O sentimento ou maneira de concepção de pensamentos meramente concebidos é distinto do sentimento de pensamentos nos quais cremos. Do mesmo modo, paixões suscitadas por encenação poética e trágica sentem diferentemente das paixões da vida real - "uma paixão que, na vida real, é desagradável, pode proporcionar o mais elevado entretenimento em uma tragédia ou poema épico". O medo e terror que está na raiz da religião é próximo deste último. Poderíamos dizer que pensamento indolente, inclinando-se à descrença, propicia paixões religiosas, pois:

Em questões de religião, os homens têm prazer em sentir medo, e os pregadores mais populares são os que despertam as paixões mais lúgubres e sombrias. Nos afazeres cotidianos [common affairs of life], quando estamos mergulhados na materialidade sensível dos assuntos tratados, nada pode ser mais desagradável que o medo e o terror. Somente nos espetáculos dramáticos e nos sermões religiosos estes podem nos dar prazer. Aqui, a imaginação repousa indolentemente sobre a ideia; e a paixão, suavizada pela falta de crença no tema, tem apenas o agradável efeito de dar ânimo à mente e prender sua atenção. (T 1.3.9.15)

Em resumo, apesar das paixões fortes, a união das ideias na poesia é acidental, não causal, e o sentimento não se compara ao da probabilidade. ${ }^{26}$ Seria este o caso da religião?

Por vezes, sim. Mas a experiência religiosa descobre um novo matiz de sentimento que não é crença, mas não é a descrença da ficção. Esse

26 "Ademais, devemos lembrar que o entendimento corrige as aparências dos sentidos, e que suas ideias têm maior direito [title] a serem acreditadas, caso não sofram a resistência de dúvidas ou probabilidade oposta, mesmo que não tenham tanta força quanto semelhanças". 
estado singular ajuda-nos a conprender a avaliação moral de Hume quando ele se mostra tolerante com relação aos sistemas religiosos. Nunca predominantemente benéficos, tais sistemas podem não ser tão nocivos como esperaríamos que fossem, dadas suas doutrinas. Isso porque são "fantasias", meras aparências, não propriamente acreditadas e, portanto, destituídas de força. Em uma nota, ele observa que, apesar de arrogante e positivo, o dogma religioso não consegue transmitir convicção acerca da existência de seus objetos que se compare à da vida comum, ou à que obtemos pelo "raciocínio experimental e observação diária". Ele diz:

Tal incredulidade se deve à fraqueza da ideia que formamos sobre nossa condição futura, o que atribuo antes à falta de semelhança desta com a vida presente do que à sua grande distância de nós. (T 1.3.9.13)

\section{Diz também:}

Os católicos romanos formam certamente a seita mais zelosa de todo o mundo cristão; e, entretanto, constatamos que quase todos os membros mais sensíveis dessa comunhão censuram a Conspiração da Pólvora e o massacre de São Bartolomeu, considerando-os cruéis e bárbaros, embora tenham sido planejados ou executados contra aquelas mesmas pessoas que, sem qualquer escrúpulo, eles condenam a castigos eternos e infinitos. Tudo que podemos dizer para desculpar tal incoerência é que eles não creem realmente naquilo que afrimam a respeito de uma existência póstuma. Aliás, a melhor prova disso é essa própria incoerência. (T 1.3.9.14)

Mais uma vez, a analogia entre doutrinas católicas - transubstanciação, o sacramento da ordenação - e convenções civis - a obrigatoriedade das promesas - é iluminadora. Em ambas ocasiões, "uma certa fórmula verbal, juntamente com uma certa intenção, muda inteiramente a natureza de um objeto externo, e até mesmo de uma criatura humana" (T 3.2.5.14). Contudo, Hume observa que, enquanto um sacerdote pode invalidar suas palavras por uma intenção secreta, a forma das palavras valida um contrato, à revelia das intenções ocultas das partes. Se não o fizesse, diversos e graves problemas poderiam surgir.

Deveríamos presumir que a salvação eterna é de maior consequência que qualquer evento mundano. Mas ela realmente o é? Uma explicação para a relativa indiferença à intenção do sacerdote está em nosso interesse maior, porque mais imediato, na vida presente. Outra explicação plausível é que, realmente, nossa crença na vida eterna não é tão forte e, por conseguinte, pouco nos importamos com suas consequências.

Na religião, pode ocorrer uma vivificação de ideias que ultrapassa a força de meras ficções. Porém, nesses casos, seria a loucura o fenômeno a que ela mais se assemelharia. Um louco é assim descrito: 
Quando a imaginação, em virtude de alguma fermentação extraordinária do sangue e dos espíritos animais, adquire uma vivacidade grande a ponto de desordenar todos os seus poderes e faculdades, não há como distinguir entre verdade e falsidade. Toda vã ficção ou ideia, tendo a mesma influência que as impressões da memória ou as conclusões do juízo, é recebida em pé de igualdade com estas, e age com igual força sobre as paixões. Agora não há mais necessidade de uma impressão presente e uma transição habitual para avivar nossas ideias. Qualquer quimera do cérebro é tão viva e intensa quanto as inferências que antes honrávamos com o nome de conclusões acerca de questões de fato; às vezes tão viva e intensa quanto as próprias impressões presentes dos sentidos. ${ }^{27}$ ( $\mathrm{T} 1.3 .10 .9$ )

Como a loucura, a religião confunde os limites entre a fantasia e a realidade. Diferentemente de poemas e romances, a força retórica tem, por vezes, o poder de elevá-la ao mesmo nível que o das crenças prováveis. E, diferentemente do sono e da febre, a confusão é duradoura e não se se explica de todo por referência a um estado fisiológico. A vividez das ideias religiosas parece oscilar entre a loucura e a poesia, ou entre crença e descrença. Com frequência, ela se establiza em um estádio intermediário. No Tratado, este estádio enriquece e complementa a psicologia e teoria da crença. Mais tarde, na "História natural da religião", História da Inglaterra e outros textos, ele virá desempenhar um grande papel explanatório em vários fenômenos característicos da existência humana.

Portanto, falando em geral, a teoria da mente de Hume no Tratado mostrase mais abrangente e completa depois da análise da religião. O conceito de crença refina-se pela distinção entre vividez, veemência e força. E a influência distintiva dos princípios de associação desenha-se com traços mais finos. Ademais, o Tratado anatomiza este tipo particular de crença, irredutível a qualquer outro. Popkin tende a tomar a religião como paradigma de toda crença, inclusive causal, para Hume. Segundo ele, o conceito de "crença" consiste no conceito de "fé", secularizado. Contrariamente a Popkin, parece-me que o Tratado elabora a descontinuidade e, mesmo, a irredutibilidade de outras crenças à crença ou fé religiosa. Nos limites de um arcabouço psicológico, ele determina as bases causais insatisfatórias, paixões predominantes, e sentimento peculiar desta última. Descobre seu caráter instável, do qual advém não apenas a ocasional aceitação tolerante de Hume, mas também suas mais profundas preocupações. Fornece-nos algumas respostas, mas acaba por sugerir uma perturbadora nova questão: o que faz com que uma crença tão

27 Em outras palavras: "A poesia e a loucura têm em comum o fato de que a vividez que conferem às ideias não é derivada das situações ou conexões particulares dos objetos dessas ideias, mas do humor e disposição da pessoa naquele momento" (T 1.3.10.10). 
pouco sustentada pelas propriedades estáveis da mente atinja o nível de força, poder e consequência tão dramática e frequentemente observados no mundo e nas vidas humanas? Depois do Tratado, Hume, o anatomista, terá que se impor a tarefa de investigar os meios que nos permitam regulá-la, quando não extirpá-la.

\section{Conclusão}

A análise de Hume sobre a religião recobre um domínio extenso, onde cada texto complementa os demais. Com respeito à justificação da crença religiosa, desafia as pretensões da revelação ("Dos milagres"), o argumento pelo desígnio, o argumento cosmológico e, mais difusamente, argumentos fideístas (Diálogos sobre a religião natural e "De uma providência particular e de um estado futuro"). Apresenta uma exame da origem da crença religiosa nas paixões e circunstâncias humanas ("História natural da religião" e "Da superstição e do entusiasmo"). Avalia os efeitos da religião na felicidade individual, bem estar social, e estabilidade política. Argumenta que a religião é desnecessária e pode ser perniciosa na moral (Uma investigação sobre os princípios da moral). Além da jutificação, causas e efeitos, morais e cognitivas, individuais e coletivas da crença, Hume esboça uma tipologia das religiões (politeísta e monoteísta, vulgar e não-vulgar, supersticiosa e entusiástica). $\mathrm{Na}$ criação de personagens exemplares, ele opõe o zelota ao filósofo, monges e sacerdotes aos membros do partido da humanidade. Assim, a "História natural" aborda a origem da religião na natureza humana, os Diálogos, sua fudamentacão racional; "Dos milagres", as credenciais da revelação. A segunda Investigação e a História da Inglaterra, seu alcance moral e político, e assim por diante.

O Tratado apenas vislumbra tais desdobramentos futuros. É significativo o fato de Hume não se ocupar explicitamente da avalição moral desta crença senão depois do Tratado. Na segunda Investigação, o artifício da justiça é mais uma vez comparado à superstição religiosa, dado que a ambos faltam fundamentos. Mas, agora, emerge um novo tom, avaliativo: enquanto a superstição é frívola, inútil e onerosa, a justiça é "absolutamente necessária para o bem-estar da humanidade e para a existência da sociedade" (EPM 3.38).

$\mathrm{Na}$ Investigação, Hume afirma que as religiões cometem uma violência contra a natureza. Ele aponta a dor e miséria que elas desnecessariamente adicionam às vidas dos religionistas. Ele nota que práticas e observâncias religiosas criam novos sentimentos de aprovação e desgosto, contraditórios aos princípios morais naturais. Entre homens do mundo, não há superstição 
que tenha o poder de "perverter inteiramente" os sentimentos naturais. Mas pessoas não mundanas (como "um fanático sombrio e ignorante", um "gloomy, hair-brained enthusiast") substituem as virtudes naturais pelas monásticas: "celibato, jejum, penitência, mortificação, negação de si próprio, submissão, silêncio, solidão" (EPM 9.3).

O Tratado também apenas vislumbra paradoxos que se mostrarão bem mais explícitos na obra futura de Hume. A segunda Investigação afirma que, mesmo não acreditadas com profundidade, as crenças religiosas persistem. E que, embora sentimentos religiosos sejam naturais, exceto àqueles dotados de um temperamento filosófico cético, sua operação é temporária. Na História da Inglaterra, Hume diz:

Os sentimentos religiosos são tão agradáveis à mente humana que é impossível fingir-se por muito tempo santos fervores sem se sentir uma parcela do fervor fngido. E, por outro lado, tão precária e temporária, dada a fraqueza da natureza humana, é a operação destas visões espirituais, que os êxtases religiosos, se empregados com constância, frequentemente devem ser fingidos, e devem ser desvirtuados por aqueles motivos mais familiares do interesse e da ambição que, insensivelmente, apoderamse da mente. ${ }^{28}$

Mais intrigante, emergindo sobre bases fracas e instáveis, a religião pode se elevar a níveis de fantismo perigosos, e poderosamente afetar a sociedade e determinar a vontade. Até mesmo em eras ilustradas, apesar do remédio do ceticismo e da reflexão, Hume concede, a fé continua perturbando os homens.

Estas tensões e paradoxos exibem a condição humana, desvelam um componente cético na análise naturalista da crença, e propõem o problema ao qual Hume vem a dedicar seus maiores esforços após o Tratado: como lidar com costume, educação, preconceito, ignorância, e paixão? De onde vem a força da religião? E de onde vem sua fraqueza? Espero que estas questões e a perplexidade que elas implicam evoquem, mesmo que brevemente, o legado de Popkin para a interpretação de Hume. ${ }^{29}$

28 No original: "So congenial to the human mind are religious sentiments, that it is impossible to counterfeit long these holy fervours, without feeling some share of the assumed warmth. And, on the other hand, so precarious and temporary, from the frailty of human nature, is the operation of these spiritual views, that the religious ecstasies, if constantly employed, must often be counterfeit, and must be warped by those more familiar motives of interest and ambition, which insensibly gain upon the mind". Hume, David. The History of England, 6 vols. Indianapolis: Liberty, 1983, vol. V, fn. aa, 572.

29 Apresentei uma versão preliminar deste ensaio no congresso "Skepticism from the Renaissance to the Enlightenment: a conference in memory of Richard H. Popkin (1923-2005)", Belo Horizonte (outubro 2007). Sou muito grata a todos os participantes e pelos valiosos conselhos e comentários. Gostaria de agradecer especialmente a José R. Maia Neto e John Christian Laursen. Esta pesquisa teve o auxílio da CAPES (Coordenação de Aperfeiçoamento de Pessoal de Nível Superior), CNPq (Conselho Nacional para 


\section{Referências bibliográficas}

FIESER, James. Early Responses to Hume's Life and Reputation, 2 vols. Bristol: Thoemmes Press, 2003.

HUME, David. The History of England, 6 vols. Indianapolis: Liberty, 1983, vol. V. 2000.

. Tratado da natureza humana. Trad. Déborah Danowski, São Paulo: UNESP,

. A Treatise of Human Nature. David Fate Norton e Mary J. Norton (eds.), Oxford: Oxford University Press, 2000.

. An Enquiry concerning Human Understanding. T. Beauchamp (ed.), Oxford: Oxford University Press, 1999.

. An Enquiry concerning the Principles of Morals. T. Beauchamp (ed.), Oxford: Oxford University Press, 1998.

. Investigações sobre o entendimento humano e sobre os princípios da moral. Trad. José Oscar de Almeida Marques. São Paulo: UNESP, 2003.

KAIL, Peter. "Understanding Hume's Natural History of Religion", Philosophical Quarterly 87 (227): 190-211.

POPKIN, Richard H., The High Road to Pyrrhonism. San Diego: Austin Hill Press, 1980.

. História do Ceticismo de Erasmo a Spinoza. Trad. Danilo Marcondes de Souza Filho, Rio de Janeiro: Francisco Alves, 2000.

. The History of Scepticism from Erasmus to Spinoza. Berkeley and Los Angeles: University of California Press, 1979.

POPKIN, Richard H., Ezequiel de OLASO e Giorgio TONELLI, Scepticism in the Enlightenment. Dordrecht: Kluwer, 1997.

RUSSELL, Paul. Freedom and Moral Sentiment. Oxford: Oxford University Press, 1995. 